University of Nebraska - Lincoln

DigitalCommons@University of Nebraska - Lincoln

Faculty Publications from the Harold W. Manter Laboratory of Parasitology

February 1994

\title{
A New Species of Heterorhabditis from the Hawaiian Islands
}

Scott Lyell Gardner

University of Nebraska - Lincoln, slg@unl.edu

S. Patricia Stock

University of Arizona, spstock@ag.arizona.edu

Harry K. Kaya

University of California, Davis, hkkaya@ucdavis.edu

Follow this and additional works at: https://digitalcommons.unl.edu/parasitologyfacpubs

Part of the Parasitology Commons

Gardner, Scott Lyell; Stock, S. Patricia; and Kaya, Harry K., "A New Species of Heterorhabditis from the Hawaiian Islands" (1994). Faculty Publications from the Harold W. Manter Laboratory of Parasitology. 27. https://digitalcommons.unl.edu/parasitologyfacpubs/27

This Article is brought to you for free and open access by the Parasitology, Harold W. Manter Laboratory of at DigitalCommons@University of Nebraska - Lincoln. It has been accepted for inclusion in Faculty Publications from the Harold W. Manter Laboratory of Parasitology by an authorized administrator of DigitalCommons@University of Nebraska - Lincoln. 


\title{
A NEW SPECIES OF HETERORHABDITIS FROM THE HAWAIIAN ISLANDS
}

\author{
Scott L. Gardner, S. Patricia Stock*, and Harry K. Kaya \\ Department of Nematology, University of California, Davis, Davis, California 95616-8668
}

\begin{abstract}
A new species of nematode of the genus Heterorhabditis (Nemata: Heterorhabditidae) was found during a survey of the soil entomopathogenic nematode fauna of the Hawaiian Islands. Heterorhabditis hawaiiensis sp. $\mathrm{n}$. can be separated from all other species of Heterorhabditis by the length of the infective juvenile and the morphological characters of the spicules, gubernaculum, and bursa. Random amplified polymorphic DNA (RAPD) fragment analysis showed that this species also has a distinct genetic pattern in RAPD bands relative to the other 6 species or isolates of Heterorhabditis that were compared.
\end{abstract}

Entomopathogenic nematodes of the genus Heterorhabditis Poinar, 1975, are being investigated as agents for biological control of soilinhabiting insects (Gaugler and Kaya, 1990). Free-living infective third-stage juveniles $\left(\mathrm{J}_{3}\right)$ locate and enter a suitable insect host through natural body openings (mouth, anus, or spiracles) and penetrate into the hemocoel. Infective nematodes can also penetrate into the hemocoel through thin areas of the insect's cuticle (Bedding and Molyneux, 1982). Once in the insect, the nematodes release symbiotic bacteria, Photorhabdus luminescens (Poinar and Thomas, 1976), from their intestinal tracts. The bacteria multiply and kill the insect host, and the nematodes feed on bacteria, becoming hermaphroditic adults. Hermaphroditic adults produce progeny that develop into both males and females. These adults mate and females produce infective-stage juveniles that leave the cadaver of the insect (Poinar, 1990; Dix et al., 1992).

Heterorhabditid nematodes are cosmopolitan (Poinar, 1990; Poinar et al., 1992) with all described species showing allopatric distributions. Presently, 4 species of nematodes are assigned to the genus Heterorhabditis. Heterorhabditis bacteriophora Poinar, 1975, was described from specimens isolated from Brecon, Australia (Poinar, 1975). Heterorhabditis heliothidis (Khan, Brooks, and Hirschmann, 1976) from North Carolina subsequently was determined to be conspecific with Heterorhabditis bacteriophora (see Poinar, 1990). Heterorhabditis zealandica Poinar, 1990, originally described as a New Zealand

Received 26 March 1993; revised 13 September 1993; accepted 20 September 1993.

* Centro de Estudios Parasitológicos y de Vectores, Calle 2, No. 584, 1900 La Plata, Buenos Aires, Argentina. population of $H$. heliothidis by Wouts (1979), was reassigned by Poinar (1990). Heterorhabditis megidis Poinar, Jackson, and Klein, 1987, was isolated from infected insects from Ohio. Heterorhabditis indicus Poinar, Karunakar, and David, 1992, was described from specimens collected in Tamil Nadu, India. In addition, a possible new species of Heterorhabditis recently has been isolated from Argentina.

Many other uncharacterized and taxonomically unstudied populations of nematodes of the genus Heterorhabditis exist in nature, and various "isolates," "strains," or "biotypes," with a percentage of them likely representing undescribed species, are being cultured in laboratories around the world.

During a survey of the diversity of entomopathogenic nematodes of Hawaii (Hara et al., 1991), several populations representing a new species of the genus Heterorhabditis were isolated from soil using trap-insects. Investigation of morphological and genetic variation in these nematodes revealed that characters were appreciably different from those described previously. Herein we describe these nematodes as a new species.

\section{MATERIALS AND METHODS}

Nematodes were isolated from soil using trap-insects, Galleria mellonella (Linnaeus), and maintained in culture in our laboratory (see Hara et al., 1991). Standard methods of in vivo culturing on $G$. mellonella were followed to obtain different stages that were measured (Woodring and Kaya, 1988). Nematodes recovered from $G$. mellonella were fixed in triethanolamine formalin (TAF) (Woodring and Kaya, 1988) and cleared in either lactophenol or glycerol and lactic acid. Quantitative measurements were made using a Leitz Ortholux II microscope equipped with an ocular micrometer or Jandel ${ }^{\mathrm{TM}}$ software and video digitizer. Drawings were made with the aid of a drawing tube. All measurements are given in micrometers with means following in parentheses unless otherwise indicated. 
Methods of random amplified polymorphic DNA (RAPD) extraction and analysis generally follow Caswell-Chen et al. (1992) with the following modifications: Several thousand infective juveniles collected from 14-day-old cultures of nematodes in G. mellonella were washed in buffered saline 5 times and then in $95 \%$ ethanol (EtOH) 5 times. They were then transferred to fresh $95 \% \mathrm{EtOH}$ for storage. Several thousand alcohol-preserved infective juveniles $(0.07 \mathrm{~g}$ wet weight) were transferred to a glass homogenizing tube containing extraction buffer $(100 \mathrm{mM}$ ethylene diamine tetraacetic acid, $\mathrm{pH} 8.0 ; 0.5 \%$ sodium lauryl sulfate; $50 \mu \mathrm{g} /$ $\mathrm{ml}$ proteinase $\mathrm{K}$ ), homogenized on ice at 1-2 $\mathrm{C}$, and transferred to a 1.5-ml Eppendorf ${ }^{\mathrm{TM}}$ tube. Extraction buffer was added to make a final volume of $500 \mu \mathrm{l}$. This was incubated in a water bath at $50 \mathrm{C}$ for $2 \mathrm{hr}$. To remove proteins and other cellular debris, $500 \mu \mathrm{l}$ of phenol/chloroform/isoamyl alcohol (25:24:1) was added to the tube and centrifuged at $16,000 \mathrm{~g}$ for 15 $\min$ at $21 \mathrm{C}$. DNA was precipitated from the supernatant portion with $1 / 10$ volume of $3 \mathrm{M} \mathrm{NaAc}, \mathrm{pH}$ 5.5 , and 3 volumes of $95 \% \mathrm{EtOH}$. The precipitate was resuspended in TE buffer ( $\mathrm{pH} 8.0)$ and used directly for polymerase chain reactions (PCR) for the RAPD analysis. Operon ${ }^{\mathrm{TM}}$ random primers (A-05, A-13, B-1, B-4) of 10 bases long were used for all reaction experiments with an annealing temperature of $35 \mathrm{C}$.

Spectrophotometric measurement of DNA samples extracted from each species was conducted to ensure that the solution concentration of template DNA remained at $10 \mathrm{ng} / \mu \mathrm{l}$. Purified DNA from the nematode genome was subjected to the PCR reaction, and the amplified DNA was run on a $1.7 \%$ horizontal agarose gel following the conditions used by Caswell-Chen et al. (1992). Products of the reaction were imaged by staining with ethidium bromide. All species or isolates were included on each gel and only 1 RAPD primer was visualized for each gel run. To decrease the probability that variation due to artifact would disrupt the pattern of true DNA polymorphism visible when reading the gel, each species or isolate was duplicated in the PCR experiment and the duplicate and original were run side by side on the same gel.

Banding patterns were resolved following the method of Caswell-Chen et al. (1992). Photographs were taken of each gel and bands were scored from the photographs as present or absent for each isolate. Jaccards' coefficient of similarity was computed based on the pattern of shared and unshared bands on each gel and a matrix of similarity values for each taxon or strain was constructed from scored RAPD fragments (see Caswell-Chen et al., 1992).

\section{Description \\ Heterorhabditis hawaiiensis n. sp. \\ (Figs. 1-16)}

General: Head truncated, or slightly rounded. Six distinct protruding lips surrounding the mouth with 6 papillae on the inner lips and 10 papillae in the outer labial region, 2 pairs dorsal, 1 lateral papilla on each side, slightly posterior to each amphid, and 2 pairs ventral. Amphids oval. Cheilorhabdions represented as refractile areas. Pro- and mesorhabdions reduced, bearing small teeth. Telorhabdions also reduced, leading directly into the esophageal lumen. Esophagus without metacorpus but with an isthmus and a basal bulb that lacks valve. Nerve ring in middle of isthmus. Excretory pore posterior to basal bulb.

Females with paired ovaries. Hermaphroditic females (first generation) with an ovotestis. Functional vulva for oviposition with protruding lips, near middle of body. Vulva of amphimictic females (second generation) with hardened deposit, evidently nonfunctional. Tail of females pointed, with a postanal swelling present only in hermaphroditic females.

Males with single testis, reflexed twice. Spicules paired, separated and slightly curved, mostly equal in size. Manubrium well set off from calomus. Calomus short, lamina with $1 \mathrm{rib}$. Gubernaculum half the length of spicules, with broad crura, visible in lateral view. Bursa peloderan attended by complement of 9 pairs of genital papillae with 3 pairs preanal and 6 pairs postanal arranged in 2 sets of 3 . Pairs 5, 7, and 8 not reaching rim of bursal membrane.

Infective juveniles represented by the third stage. Cuticle with fine longitudinal striations. Mouth and anus closed. Nerve ring in the middle of isthmus. Opening of excretory pore located at level of basal bulb.

Male $(\mathrm{n}=20)$ : Length 864-1,130 (1,000). Maximum width 49-84 (63). Stoma length 4-8 (7). Stoma width 4-6 (5). Distance from anterior end to nerve ring 67-112 (84). Distance from anterior end to excretory pore 71-146 (130). Esophagus length 100-149 (118). Reflexion of testes 115-198 (168). Tail length 26-40 (34). Width at cloaca 21-39 (27). Right spicule $(\mathrm{n}=$ 20) 42-50 (46) long, 3-5 (4) wide at manubrium, manubrium 2-4 (3) long, and 5-7 (6) at maximum width. Left spicule $(n=20)$ 40-51 (47) long, 3-5 (4) wide at manubrium, manubrium 2-5 (3) long, 5-7 (6) at maximum width. Gubernaculum 18-26 (22) long, 1.6-2.8 (1.9) wide.

Amphimictic female $(\mathrm{n}=20)$ : Length $1.3-2.3 \mathrm{~mm}$ (1.8 mm). Maximum width 104-171 (139). Stoma length 6-12 (9). Stoma width 5-10 (7). Distance from anterior end to nerve ring 78-116 (99). Distance from anterior end to excretory pore 116-175 (153). Esophagus 110-153 (137) long. Vulva situated from 49 to $56 \%(52 \%)$ of body length. Tail length 49-87 (63). Width at anus 20-35 (29).

Hermaphroditic female $(\mathrm{n}=20)$ : Length 4-7 mm (5). Maximum width 270-376 (337). Stoma length 913 (12). Stoma width 7-12 (9). Distance from anterior end to nerve ring 102-212 (159). Distance from anterior end to excretory pore 219-318 (267). Esophagus length 187-283 (235). Vulva situated from 41 to $50 \%$ (46\%) of body length. Tail length 67-98 (84). Width at anus 38-79 (56).

Infective juveniles (third juvenile stage) $(\mathrm{n}=20)$ : Length 506-631 (575). Maximum width 21-28 (25). Distance from anterior end to nerve ring 79-103 (92). Distance from anterior end to excretory pore 95-132 (114). Esophagus length 115-181 (133). Tail length 82108 (90).

\section{Taxonomic summary}

Symbiotype: Unknown in nature, from trap-insect in sandy loam under ironwood tree (Casuarina equisetifolia Linnaeus).

Type locality: Hanalei, $0.5 \mathrm{~m}$, Island of Kauai, Hawaii $\left(22^{\circ} 12^{\prime} \mathrm{N}, 159^{\circ} 30^{\prime} \mathrm{W}\right)$. 

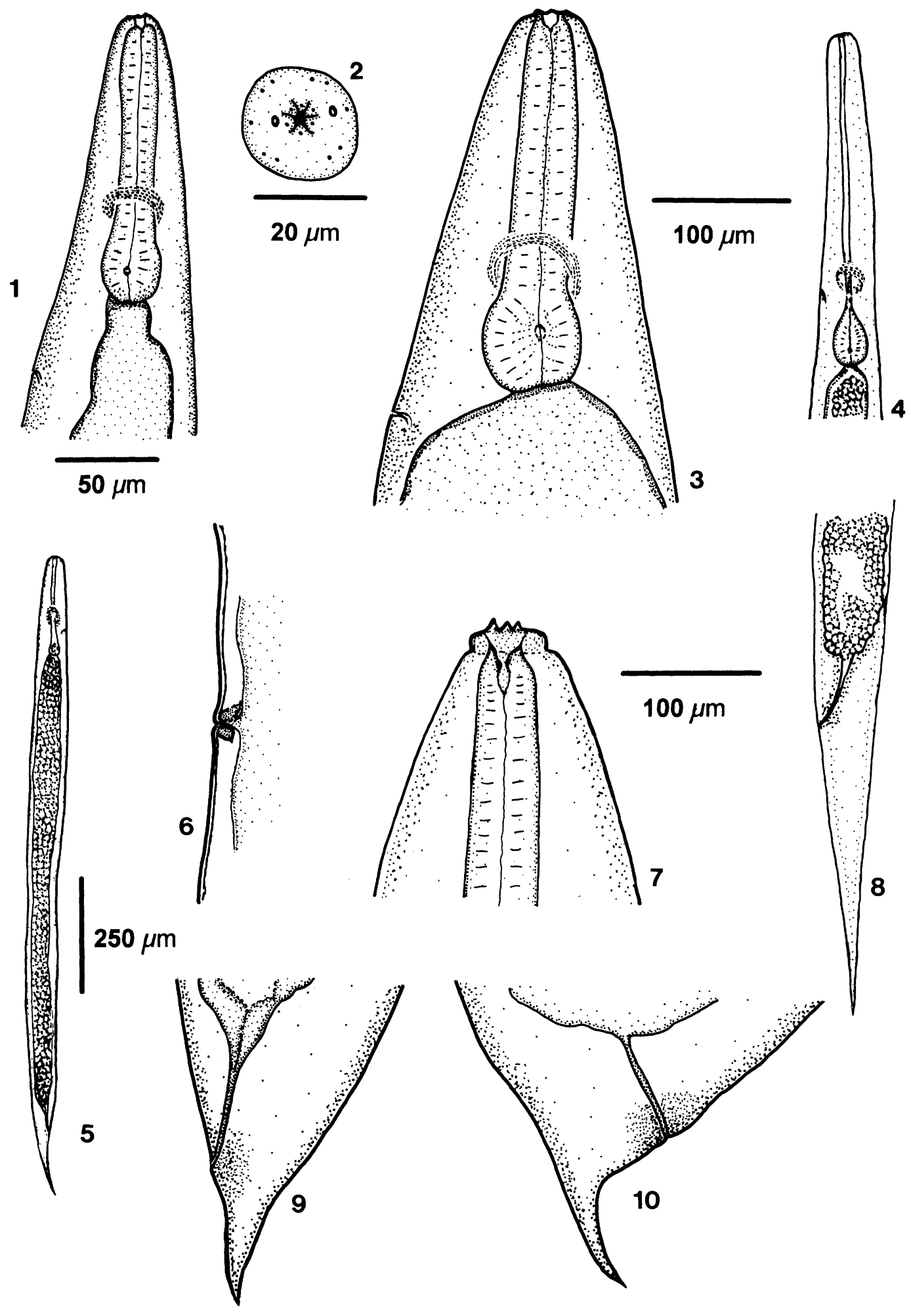
TABLE I. Similarity matrix based on Jaccards' coefficient of shared random amplified polymorphic DNA(RAPD) bands among 7 species and isolates of Heterorhabditis.*

\begin{tabular}{|c|c|c|c|c|c|c|c|c|}
\hline $\begin{array}{c}\text { Species or strain } \\
\text { of Heterorhabditis† }\end{array}$ & 1 & 2 & 3 & 4 & 5 & 6 & 7 & 8 \\
\hline H. sp. 1 Argentina & 1.0000000 & & & & & & & \\
\hline H. bacteriophora & 0.4660194 & 1.0000000 & & & & & & \\
\hline H. megidis & 0.2363636 & 0.1864407 & 1.0000000 & & & & & \\
\hline H. sp. 2 Davis & 0.8987342 & 0.4509804 & 0.2363636 & 1.0000000 & & & & \\
\hline$H$. sp. 3 Tasmania & 0.2053571 & 0.1983471 & 0.8591549 & 0.1891892 & 1.0000000 & & & \\
\hline H. hawaiiensis & 0.1417323 & 0.1297710 & 0.1769912 & 0.1583333 & 0.1810345 & 1.0000000 & & \\
\hline H. zealandica & 0.1742424 & 0.1641791 & 0.2018349 & 0.1666667 & 0.2477064 & 0.2265625 & 1.0000000 & \\
\hline S. carpocapsae & 0.1884058 & 0.2248062 & 0.2212389 & 0.1739130 & 0.2231405 & 0.1510791 & 0.1857143 & 1.0000000 \\
\hline
\end{tabular}

Specimens deposited: Holotype male, University of California Davis Nematode Collection number (UCDNC) UCDNC 3234, field collection number KH3. Allotype amphimictic female, UCDNC 3235. Paratypes, 5 males UCDNC 3236, 5 amphimictic females UCDNC 3237, 5 hermaphroditic females UCDNC 3238, 5 infective juveniles UCDNC 3239.

Etymology: This species was named after the geographic locality from which it was found.

\section{Remarks}

Heterorhabditis hawaiiensis can be distinguished easily from all previously described species of Heterorhabditis except $H$. indicus by having much shorter infective juveniles. Heterorhabditis hawaiiensis can be separated from $H$. indicus by having spicules differing in overall shape, with $H$. hawaiiensis having a more well developed manubrium and the lamina with a ventral expansion, and in the more pronounced development of the bursal rays (cf. Figs. 11-15 with fig. 4 in Poinar et al. [1992]). In addition, the genetic profiles generated by RAPD fragment analysis show that this species is distinct, sharing a maximum of $18 \%$ of the RAPD bands (Table I) with the other 6 heterorhabditid isolates and/or species that we analyzed (Fig. 17).

\section{DISCUSSION}

Despite the importance of nematodes of the genus Heterorhabditis in biological control, few robust quantitative studies of morphological and genetic variation in Heterorhabditis have been published (see, however, Akhurst, 1987; Curran, 1990). Usually, some knowledge of the extent of morphological or genetic variation of the population and the species is required before a specimen can be assigned to its proper species.

The morphological characteristics of small rhabditid bacterial-feeding nematodes are believed to be difficult to study (Dix et al., 1992). Relative to nematodes of the genus Heterorhabditis, Dix et al. (1992) stated “. .. the extent of overlap in morphometric characters is such that, with the possible exception of $H$. megidis, no one individual from a population can be reliably assigned to a particular species." The lack of comparative data makes it difficult to assign individuals of these nematodes to a correct species using only morphological characters. However, with the advent of PCR techniques, unambiguous and rapid identifications of even single juvenile nematodes now should be realized.

For diagnosis of species or strains of nematodes, RAPD fragments constitute a welcome addition to sometimes scarce morphological characters. Although extreme care must be taken in the collection, preparation, and analysis of DNA for study of RAPDs, patterns can be generated relatively easily and quickly (Williams et al., 1990; Ellsworth et al., 1992). RAPD markers have been shown to work well for genetic analysis with the absence of a band in 1 taxon being attributed to the lack of amplification of the DNA due to loss

FIGURES 1-10. Morphological characteristics of Heterorhabditis hawaiiensis from Hawaii. 1. Anterior end of male. 2. En face view of amphimictic female. 3. Anterior end of amphimictic female. 4. Anterior end of infective third-stage juvenile. 5. Infective juvenile, whole body view. 6. Region of the vulva of amphimictic female. 7. Anterior end of amphimictic female. 8. Posterior view of infective juvenile. 9, 10. Posterior ends of hermaphroditic females. Scale bar for Figures 3, 4 and 6-10, same. 

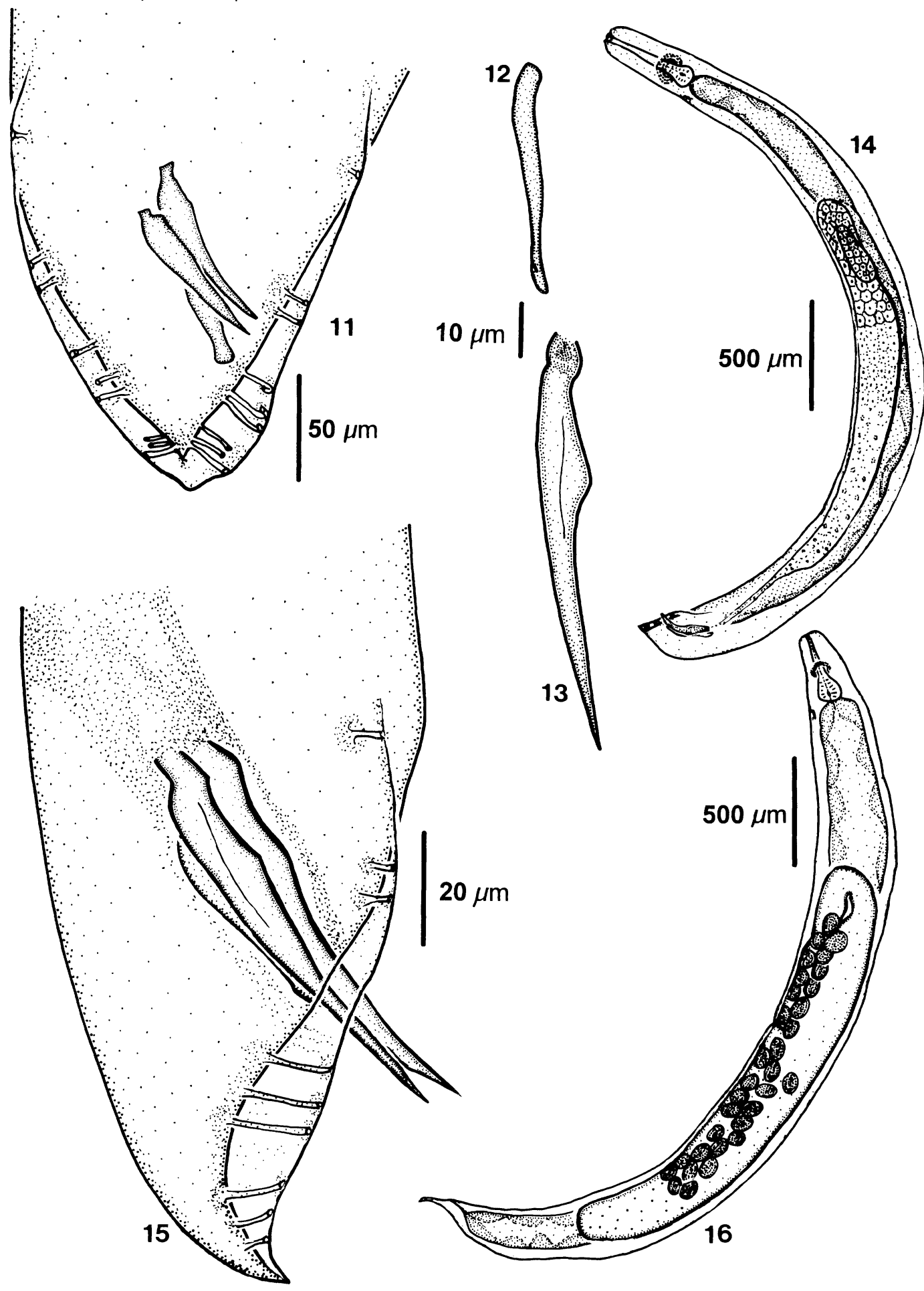

FIGURES 11-16. Morphological characteristics of Heterorhabditis hawaiiensis from Hawaii. 11. Posterior end, ventral view male. 12. Gubernaculum, lateral view. 13. Right spicule, lateral view. 14. Whole male, lateral view. 


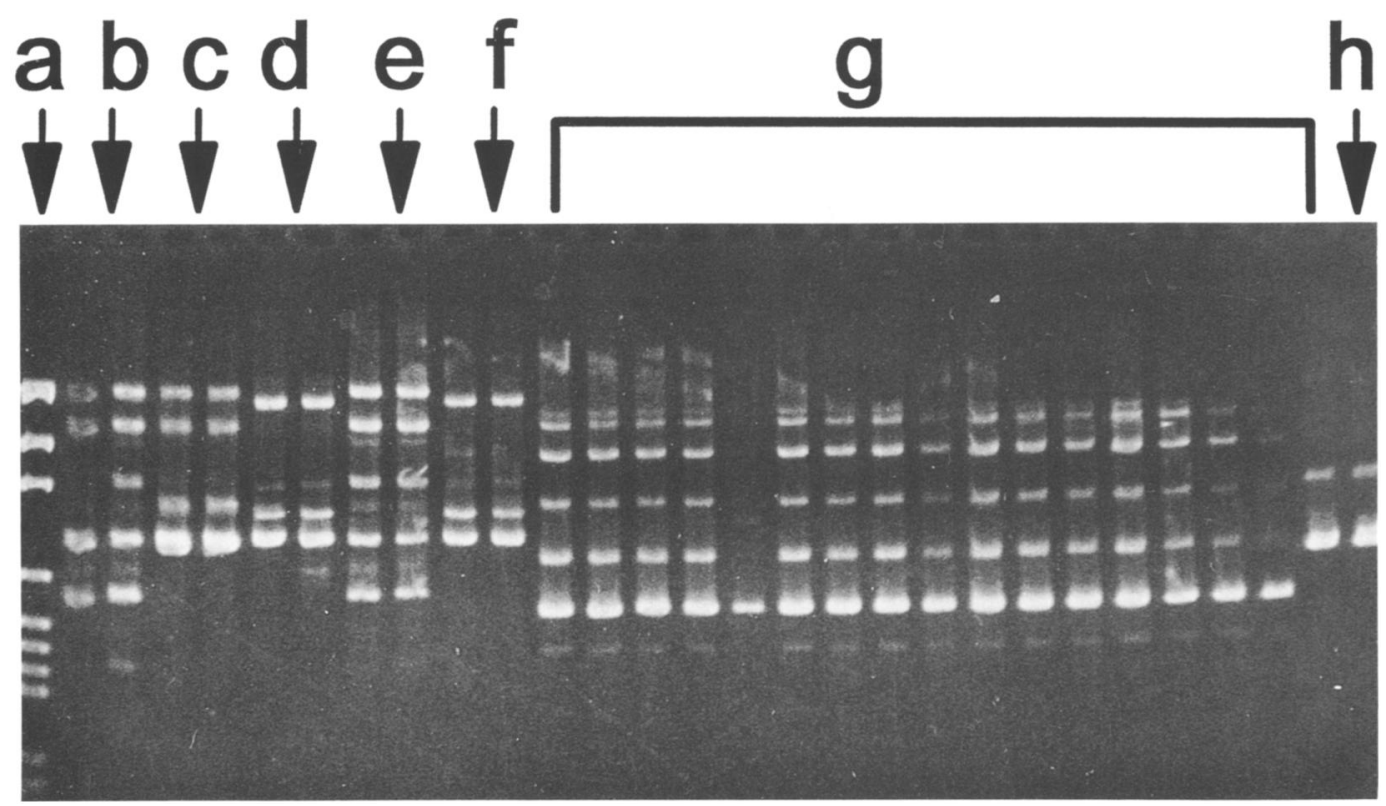

FIGURE 17. Random amplified polymorphic DNA (RAPD) fragments from isolates of 6 species/strains of Heterorhabditis and 1 species of Steinernema. For each presumptive species/strain, the sample was duplicated on the gel to check for consistency; thus, there are 2 lanes on the gel for each species/strain. Except for the molecular size standard in the first lane, a, each arrow indicates duplicate samples. From the left: a, lane 1, the molecular size RAPD standard; b, lanes 2, 3, undescribed species of Heterorhabditis from Argentina; c, lanes 4, 5, $\mathrm{H}$. bacteriophora; d, lanes $6,7, \mathrm{H}$. megidis; e, lanes 8,9 , uncharacterized species of Heterorhabditis from Davis, California; f, lanes 10, 11, uncharacterized Heterorhabditis from northern California; g, lanes 12-27, RAPD band patterns for 8 isolates of $H$. hawaiiensis $\mathrm{n}$. sp.; h, lanes 28, 29, Steinernema glaseri. Note the distinct nature of the band patterns of $H$. hawaiiensis relative to the other strains and species surveyed.

of the DNA priming site by mutation, i.e., deletion or insertion (Williams et al., 1990). The RAPD patterns that we demonstrated in this study serve well for diagnosis and, in the future, may possibly be used for characters in phylogenetic analyses.

\section{ACKNOWLEDGMENTS}

We especially thank Frances $F$. Wu for technical assistance in DNA analyses. This work was supported in part by National Science Foundation grant BSR-9024816 to S.L.G., by grant number 9386 from the University of California Genetic Resources Conservation Program to S.L.G. and H.K.K., and by a grant from the International Foundation for Science, Stockholm, Sweden, to S.P.S.

\section{LITERATURE CITED}

AkHuRst, R. J. 1987. Use of starch gel electrophoresis in the taxonomy of the genus Heterorhabditis (Nematoda: Heterorhabditidae). Nematologica 33: $1-9$.

Bedding, R. A., ANd A. S. Molyneux. 1982. Penetration of insect cuticle by infective juveniles of Heterorhabditis spp. (Heterorhabditidae: Nematoda). Nematologica 28: 354-359.

Caswell-Chen, E., V. M. Williamson, and F. F. Wu. 1992. Random amplified polymorphic DNA analysis of Heterodera cruciferae and $H$. schactii populations. Journal of Nematology 24: 343-351.

CurRaN, J. 1990. Molecular techniques in taxonomy. In Entomopathogenic nematodes in biological control, R. Gaugler and H. K. Kaya (eds.). CRC Press, Boca Raton, Florida, p. 63-74.

DiX, I., A. M. Burnell, C. T. Griffin, S. A. Joyce, M. J. Nuget, AND M. J. Downes. 1992. The identification of biological species in the genus Heterorhabditis (Nematoda: Heterorhabditidae)

15. Posterior end of male, right lateral view. 16. Whole amphimictic female, left lateral view. Scale bars same for Figures 12, 13. 
by cross-breeding second generation amphimictic adults. Parasitology 104: 509-518.

Ellsworth, D. L., K. D. Rittenhouse, AND R. L. HONEYCUTT. 1992. Artifactual variation in randomly amplified polymorphic DNA banding patterns. BioTechniques 14: 214-217.

GAUGleR, R., AND H. K. KAYA. 1990. Entomopathogenic nematodes in biological control. CRC Press, Boca Raton, Florida, 365 p.

Hara, A. H., R. Gaugler, H. K. Kaya, AND L. M. LEBECK. 1991. Natural populations of entomopathogenic nematodes (Rhabditida: Heterorhabditidae, Steinernematidae) from the Hawaiian Islands. Environmental Entomology 20: 211-216.

PoINAR, G. O., JR. 1975. Description and biology of a new insect parasitic rhabditoid Heterorhabditis bacteriophora $\mathrm{n}$. gen., n. sp. (Rhabditida; Heterorhabditidae n. fam.). Nematologica 21: 463-470.

. 1990. Taxonomy and biology of Steinernematidae and Heterorhabditidae. In Entomopathogenic nematodes in biological control, R. Gaugler and H. K. Kaya (eds.). CRC Press, Boca Raton, Florida, p. 23-61.

, G. K. Karunakar, AND H. David. 1992. Heterorhabditis indicus $\mathbf{n}$. sp. (Rhabditida: Nematoda) from India: Separation of Heterorhabditis spp. by infective juveniles. Fundamentals of Applied Nematology 15: 467-472.

Williams, J. G. K., A. R. Kublik, K. J. Livak, J. A. RAFAlSKI, AND S. V. TINGEY. 1990. DNA polymorphisms amplified by arbitrary primers are useful as genetic markers. Nucleic Acids Research 120: 6531-6535.

WoOdRING, J. L., AND H. K. KaYA. 1988. Steinernematid and heterorhabditid nematodes: A handbook of techniques. Southern Cooperative Series Bulletin 331, Arkansas Agricultural Experiment Station, Fayetteville, $31 \mathrm{p}$.

Wouts, W. M. 1979. The biology and life cycle of a New Zealand population of Heterorhabditis heliothidis (Heterorhabditidae). Nematologica 25: 191-202. 